\title{
Hollow tree fire is a useless forest fire category
}

\author{
Ivan Chromek ${ }^{1}$, Karolina Lukášováa ${ }^{*}$, Roman Berčák², Jan Vaněk², Jaroslav Holuša² \\ ${ }^{1}$ Technical University in Zvolen, Faculty of Wood Sciences and Technology, T. G. Masaryka 2117/24, SK - 96053 Zvolen, \\ Slovak Republic \\ ${ }^{2}$ Czech University of Life Sciences Prague, Faculty of Forestry and Wood Sciences, Kamýcká 129, \\ CZ - 16500 Prague 6-Suchdol, Czech Republic
}

\begin{abstract}
In the Czech Republic and Slovakia, the term "hollow tree fire" was first used in a publication in 1956 without being well defined and was then uncritically used in other publications. The term refers to fires occurring in the rotted, inner trunks of trees. The main aim of the current study was to determine whether the term should be considered a useful category for the statistical analysis of forest fires. The nature and causes of fires from 2006-2015 were assessed by performing a detailed analysis of the Fire Rescue Service of the Czech Republic (FRS CR) database. The database included a total of 7,256 fires in the natural environment, but only 18 of these were hollow tree fires. Most hollow tree fires were initiated by human carelessness, and only three were initiated by lightning. Based on our critical consideration of fire attributes, hollow tree fires should not be considered a category of forest fire. The presence of rotten trees is, however, a serious problem because such trees represent long-lasting sources of fire in forest stands and because they complicate firefighting. The numbers of rotten trees in forests is increasing, and firefighters should be made aware of the complications of extinguishing fires involving rotten trees in forests.
\end{abstract}

Keywords: rot; damage; firefighting; Norvay spruce; central Europe

Editor: Milan Zúbrik

\section{Introduction}

The term forest fire refers to fire that breaks out in and spreads through forests and other wooded land or that breaks out in nonwooded land and spreads to forests and other wooded land. The definition of "forest fire" excludes prescribed or controlled burning, which is usually conducted to reduce or eliminate the accumulated fuel on the ground (Regulation (EC) No 2152/2003 of the European Parliament). More generally, a forest fire is a complex of physico-chemical phenomena involving burning, gas exchange, and heat transfer processes that change in space and time. Forest fires have negative effects on all of the social functions of forests (Chromek 2006).

In the Czech Republic and Slovakia, forest fires are assigned to one of four categories (Nechleba 1927; Nestěrov 1949; Hendrych 1956; Pfeffer et al. 1961; Kunt 1967; Forst 1970; Stolina et al. 1985, 2001; Hlaváč 2003, 2005; Krakovský 2004; Chromek 2006; Francl 2007; Kula \& Jankovská 2013; Hlaváč \& Chromek 2016; see Table 1): surface fires (“pozemní požár” in Czech), ground fires (“podzemní požár”), crown fires (“korunový požár”), and hollow tree fires ("požár dutého stromu”).

In 2005, another kind of forest fire, a "calamity area fire”, was described (Hlaváč et al. 2005). This kind of forest fire results from many broken trees after storm winds and anthropogenic ignition, factors that were responsible for the severe fire in the High Tatras Mts in 2005. This kind of forest fire has not been recognized as a new category of fire, although its legitimacy was very well reasoned (Hlaváč et al. 2005).

The areas affected by surface fires, ground fires, crown fires, and calamity area fires are quantified annually at the national level in the Czech Republic and Slovakia (vulhm.cz; los.sk) as well as at the European level The European Forest Fire Information System - EFFIS. In contrast to these kinds of fires, which damage thousands of hectares, "hollow tree fires" initially affect only individual trees (Hendrych 1956; Pfeffer et al. 1961; Krakovský 2004; see Table 1) and cause negligible damage and loss. The Czech term for this kind of fire is "požár dutého stromu", and the term "hollow tree fire" will be used in this paper. This term was first used but was not

*Corresponding author. Karolina Lukášová, e-mail: lukasovak@fld.czu.cz, phone:+420 737322550 
clearly defined by Hendrych (1956). Since that time, the term hollow tree fire has been used without critical evaluation in many publications (Table 1).

Table 1. Overview of publications describing hollow tree fires and other kinds of forest fires in the Czech Republic and Slovakia. In the Hollow tree fires column, + or - indicates that hollow tree fires were or were not described, respectively. In the Types of forest fires column, + or - indicates that the type of fire was or was not indicated, respectively.

\begin{tabular}{|c|c|c|c|}
\hline Author & Year of publication & Hollow tree fires & Types of forest fires \\
\hline Kučera & 1914 & - & - \\
\hline Nechleba & 1927 & - & + \\
\hline Barchánek & 1932 & - & - \\
\hline Pfeffer & 1938 & - & - \\
\hline Felix & 1948 & - & - \\
\hline M. M. & 1948 & - & - \\
\hline Něstěrov & 1949 & - & + \\
\hline Turček \& Lehotan & 1949 & - & - \\
\hline Hendrych & 1956 & + & + \\
\hline Pfeffer & 1961 & + & + \\
\hline Hodr & 1963 & + & + \\
\hline Kunt & 1967 & + & + \\
\hline Forst & 1970 & + & + \\
\hline Kula & 1981 & - & - \\
\hline Stolina & 1985 & + & + \\
\hline Kula & $1985 a$ & - & - \\
\hline Kula & $1985 b$ & - & - \\
\hline Pohořelý \& Vilhelm & 1996 & - & + \\
\hline Stolina et al. & 2001 & + & + \\
\hline Křístek & 2002 & + & + \\
\hline Hlaváč & 2003 & + & + \\
\hline Franc & 2004 & - & - \\
\hline Krakovský & 2004 & + & + \\
\hline Sloup \& Raba & 2004 & - & - \\
\hline Sviták & 2004 & - & - \\
\hline Tomášek & 2004 & - & - \\
\hline Hlaváč & $2005 a$ & + & + \\
\hline Hlaváč & $2005 b$ & + & + \\
\hline Hlaváč et al. & 2005 & - & - \\
\hline Chromek & 2006 & - & + \\
\hline Francl & 2007 & - & + \\
\hline Tomášek & 2007 & - & - \\
\hline Hlaváć et al. & 2009 & - & - \\
\hline Kula \& Jankovská & 2013 & - & + \\
\hline Hlaváč \& Chromek & 2016 & + & + \\
\hline Machander & 2016 & - & - \\
\hline
\end{tabular}

Given the need for detailed analyses of the causes and natures of fires, the question arises as to whether the hollow tree fire should be recognized as a category of forest fire. The aim of this work is to quantify this kind of fire in the Czech Republic and to determine whether it warrants being recognized as a category of forest fire. The significance of rotten trees is also considered.

\section{Material and methods}

The database of fires from the territory of the Czech Republic for the period 2006-2015 was studied. The forest fire database was provided by the Fire Rescue
Service of the Czech Republic, which is hereafter abbreviated FRS CR. The database contains information for all natural environmental fires in the territory of the Czech Republic, with the exception of areas controlled by the military or by the Ministry of Defense.

The unadjusted database contained a large amount of information on each individual fire. The data include information about the fire category, the level of alarm that was announced, the date and time of the announcement, the date and time when the fire was extinguished, the location of the fire (region, district, municipality, part of municipality, coordinates), and ownership of damaged property (state, private, etc.). The data also include information on the intervention (number of fire units, fire area, direct damage, etc.), specification of fire location (fire in the natural environment, fire outside a building, etc.), initiator, cause, and comments.

We also searched online resources through Google. com search engines using the keywords "požár" (fire), "strom" (tree), and "dutý" (hollow) as a single search term (Appendix A1).

\section{Results}

Between 2006 and 2015, the FRS CR database included records for 7,256 fires in the natural environment. Only 18 of the 7,256 (i.e., $0.25 \%$ ) could be considered hollow tree fires, and these involved a total area of $26 \mathrm{~m}^{2}$ in forest stands. Most hollow tree fires in forest stands were recorded in 2007 and were usually started by human carelessness involving matches or lighters cases; hollow tree fires were started by lightening in only three cases. Most of the hollow tree fires required $<3 \mathrm{~h}$ to extinguish (Table 2).

The hollow tree fires involved beech (Fagus sylvatica L.) in four cases, Norway spruce (Picea abies L. [Karst.]) in two cases, and unrecorded species in the other cases. All 18 fires were reported between 8 am and 24 pm (Fig. 1). The fires occurred from April to December but most occurred in July (Fig. 2). The registered total damage was CZK 6,000 (approximately EUR 230), and assets valued at CZK 770,000 (EUR 29,468) were saved.

According to the FRS CR database and internet sources (Appendix A1), 11 other cases of hollow tree fires were recorded between 2006 and 2015 outside of forests ${ }^{1}$; these most often occurred in urban areas or parks (five cases in 2015 in total). The hollow tree fires were distributed randomly of the Czech Republic from 2006 to 2015 (Fig. 3).

\footnotetext{
${ }^{1}$ Forests are defined as land with tree crown cover (or equivalent stocking level) of more than $10 \%$ and area of more than 0.5 ha. The trees should be able to reach a minimum height of $5 \mathrm{~m}$ at maturity in situ. (Regulation (EC) No 2152/2003 of the European Parliament).
} 
Table 2. Information on hollow tree fires occurring in forests in the Czech Republic from 2006 to 2015.

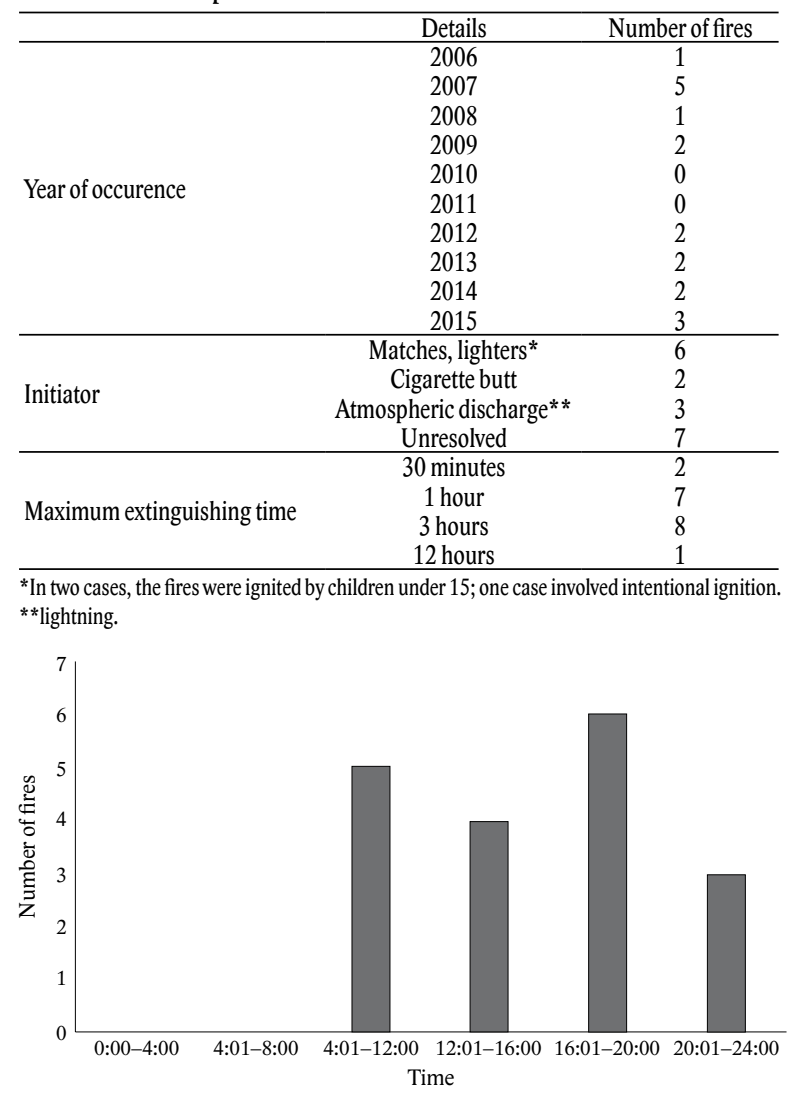

Fig. 1. Number of hollow tree fires in the Czech forests from 2006-2015 as affected by time of day.

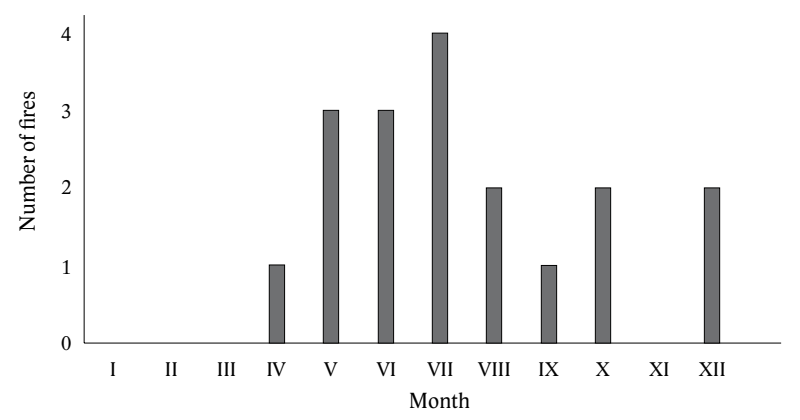

Fig. 2. Number of hollow tree fires in the Czech forests from 2006-2015 as affected by month of year.

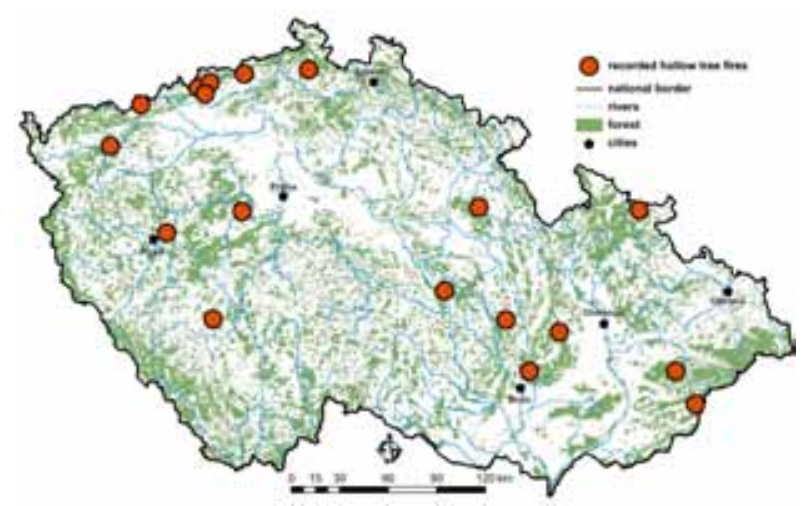

Fig. 3. Locations of hollow tree fires in the Czech Republic from 2006-2015.

\section{Causes of a hollow fire occurence}

We consider tree damage and rot and their relationship to fire in the following paragraphs.

When rocks impact trees, different types of tree failure can occur, including uprooting and trunk breakage (Berger et al. 2002). Certain species, particularly angiosperms, appear to be more resistant to failure than others and often sustain minor rather than severe wounds (Dorren \& Berger 2005). The larger the tree, the smaller the percentage of cambial damage that will occur. Some broadleaf species are able to produce scar tissue faster than fir or spruce. This scar tissue will form around the wound and protect it from pathogen attack (Shigo 1986). Wounds on silver fir (Abies alba Mill.) and Norway spruce are relatively susceptible to pathogens, leading to internal stem rot and decay and then to reduced mechanical resistance to rockfall. Thick bark can protect the living cambium from wounding (Guyette \& Stambaugh 2004). Damage from rockfall is not a widespread problem; it tends to occur only in the isolated cirques in high mountains with steep rocky slopes, as in the Giant Mts. and Bohemian Forest Mts. in the Czech Republic (Hrádek et al. 1997).

As amended under Section 20 (1) N) of Act No. 289/1995 Coll., On Forests and on Amendment and Supplementation of Certain Acts (Forestry Act), it is forbidden to graze cattle in forests or to allow cattle to move through forests in the Czech Republic.

Grazing of cattle has a long history in the Czech Republic (Svoboda 1952), but precise information on its occurrence is lacking. Although peeling, the rubbing of trunks by horns, and the trampling of roots by hooves have recently occurred in the Carpathians (Křistek 2008), quantitative data are lacking, and this kind of damage is rarely reported in scientific publications (e.g., Lutz 1980; Okada et al. 2007). There is also evidence of bark-stripping by horses in neighboring Poland (Kuiters et al. 2006; Klich 2017).

Bark-stripping and bark-peeling in European conifers by deer (Cervus elaphus L.) (Pfeffer et al. 1961; McIntyre 1972; Homolka 1995; Welsch et al. 1997) is an increasing problem in many European countries and elsewhere (e.g., see Mitchell et al. 1977; Mayer \& Ott 1991; Donaubauer 1994; Reimoser 2003; Mansson \& Jarnemo 2013). Some tree species, such as fir and ash (Fraxinus sp.), have been debarked by European bison (Klich 2015).

Each logging system can cause a different kind of damage to remaining trees. Because it potentially reduces tree vigour and increases attack by insects or diseases, logging injury to the remaining trees may lead to serious economic losses (Ohman 1970; Vasiliauskas 2001). Skinned bark and exposed sapwood, damaged roots, and broken branches are the most common forms of damage (Vasiliauskas \& Stenlid 2007). Damage may decrease the quality of residual trees and increase stand mortality 
through insect and disease infestation (Han \& Kellogg 2000; Kiser 2011). Wounding can cause stem deformity and decay and significantly reduce final crop volume and value (Meadows 1993). Stem wounds and root damage are also potential means of entry for organisms causing decay and pitch rings (Shigo 1986).

When fungi invade a wound caused by mechanical damage, the reduce wood hardness, texture, and color. Rot arises because fungi secrete a wide range of extracellular enzymes that degrade host tissues (Eriksson \& Pettersson 1968; Nord \& Hata 1969; Hüttermann 1980; Johansson 1988; Karlsson \& Stenlid 1991; Maijala et al. 1995; Asiegbu et al. 1998; Korhonen \& Stenlid 1998; Maijala et al. 2003; Asiegbu et al. 2004).

Stereum sanquinolentum (Alb. \& Schwein.) Fr. is the most common decay fungus of Norway spruce. This fungus is able to infect open wounds of live trees (Isomäki \& Kallio 1974; Atta \& Hayes 1987; Mäkinen et al. 2007). The spread and extent of the attack depend on the frequency of damage, wound age, and tree diameter at breast height (Vlad \& Sidor 2013; Vlad 2014). Other important fungal pathogens include Heterobasidon species, which cause destructive diseases of conifers in the northern temperate regions of the world, especially in Europe (Asiagbu et al. 2005). Heterobasidon spp. also attack wounds, especially those caused by logging (Rönnberg et al. 2013).

Fungal pathogens can grow rapidly through infected trees. $S$. sanguinolentum, for example, can spread up to $70 \mathrm{~cm}$ per year in tree trunks (Čermák et al. 2004a, b, c; Čermák \& Strejček 2007), and Heterobasidion spp. can spread up to $1 \mathrm{~m} \mathrm{yr}^{-1}$ in tree trunks and can grow into the trunk from infected roots (Huse \& Venn 1994). The rot caused by these pathogens spreads upward through the mature, middle part of the trunk (Černý 1989; Čermák et al. 2004b).

Rotted wood is 2.0- to 2.5-times lighter in weight than healthy wood. In addition to reducing the mechanical strength of wood, rot also changes wood color and appearance (Zeidler 2012). The rotting of wood by fungi increases its ability to burn. That fire is usually initiated by lightning or arson (Hendrych 1956; Krakovský 2004) is confirmed by our records for hollow tree fires.

When lightning strikes a healty tree, it causes mechanical damage, but when lightning strikes a tree with rot in the trunk, it causes fire. The natural occurrence of forest fires resulting from lightning stricking a dry or hollow tree is rare in the Czech Republic (Nechleba 1927; Kula 1985a). Only $2 \%$ of the forest fires were caused by lightning in 2015 (Zpráva o stavu lesa a lesního hospodářství České republiky v roce 2015 2016). This is consistent with past records. From 1992-2004, for example, Kula \& Jankovská (2013) reported that lightning caused only $1.39 \%$ of forest fires in the Czech Republic.

In 1970, 70,000 ha of spruce stands in the Czech Republic had significant levels of game damage (Černý 2001). The area of such damaged stands had increased to 106,000 ha by 1994 and to 220,000 ha by 1999 . At the beginning of the 21 st century in the Czech Republic, it was estimated that more than $20 \%$ of the total volume of harvested timber (Půlpán 2001) was damaged by rotting. The losses due to rot have continued to increase (Malík \& Karnet 2007).

According to the National Forest Inventory for the period 2014-2016, more than $13 \%$ of the trees between 41 to 60 years old in the Czech Republic had been damaged by browsing, peeling, or rubbing, and $8 \%$ of all trees in the country were damaged, regardless of age (Table 3). The damage increases with altitude (Table 4) Kučera et al. 2016.

Table 3. Percentage of trees damaged by browsing, peeling, or rubbing as affected by age class in the territory of the Czech Republic (2014-2016).

\begin{tabular}{cc}
\hline Age of forest & Browsing, peeling, or rubbing [\%] \\
\hline $1-20$ & 7.2 \\
$21-40$ & 11.0 \\
$41-60$ & 13.9 \\
$61-80$ & 8.9 \\
$81-100$ & 5.3 \\
$>100$ & 1.7 \\
Total & 8.2 \\
\hline
\end{tabular}

Table 4. Percentage of trees damaged by browsing, peeling, or rubbing as affected by altitude in the Czech Republic (20142016).

\begin{tabular}{cc}
\hline Altitude $[\mathrm{m}]$ & Browsing, peeling, or rubbing [\%] \\
\hline less than 400 & 3.5 \\
$400-700$ & 7.6 \\
$>700$ & 17.2 \\
\hline
\end{tabular}

In the case of forest fires in stands with rotting trees, flames can spread over the surface of the forest litter and ignite trees at the base of the trunk. The ideal condition for spread occurs when an ignited tree has a hole in the upper part of its trunk, creating a so-called „chimney effect“ (Pfeffer et al. 1961; Forst et al. 1970).

Although extinguishing a single, burning hollow tree is not complicated, some precautions should be followed. The trees must be felled (Fig. 4a) and, for safety, guided blasting charges (Fig. 4b) are used [see Staré Hory 2007 (enclosed pictures - Forests of the Slovak Republic, (Fig. 4c)]. Burned and felled trees must also be repeatedly inspected to ensure that they are extinguished (Fig. 4d). Even after the front of a forest fire passes through these trees, rotten trees may continue to burn and may activate the forest fire (Fig. 4e).

For reasons of safety, pyrotechnics is necessary (Fig. 4b). In such cases - directed burst charges, lightning bolts are also used for the destruction of such trees.

It is often safer to use explosive charges (for every 10 $\mathrm{cm}$ of stem thickness, single spin, thread) rather than axes and saws to fell rotten trees that have burned or are still burning.

Even when they are felled, however, the cavities of burning hollow trees may contain fire. The hidden fires in such trees create a so-called "cigarette effect" (Fig. $4 \mathrm{c}$ ), and the felled trunks must be repeatedly checked and 

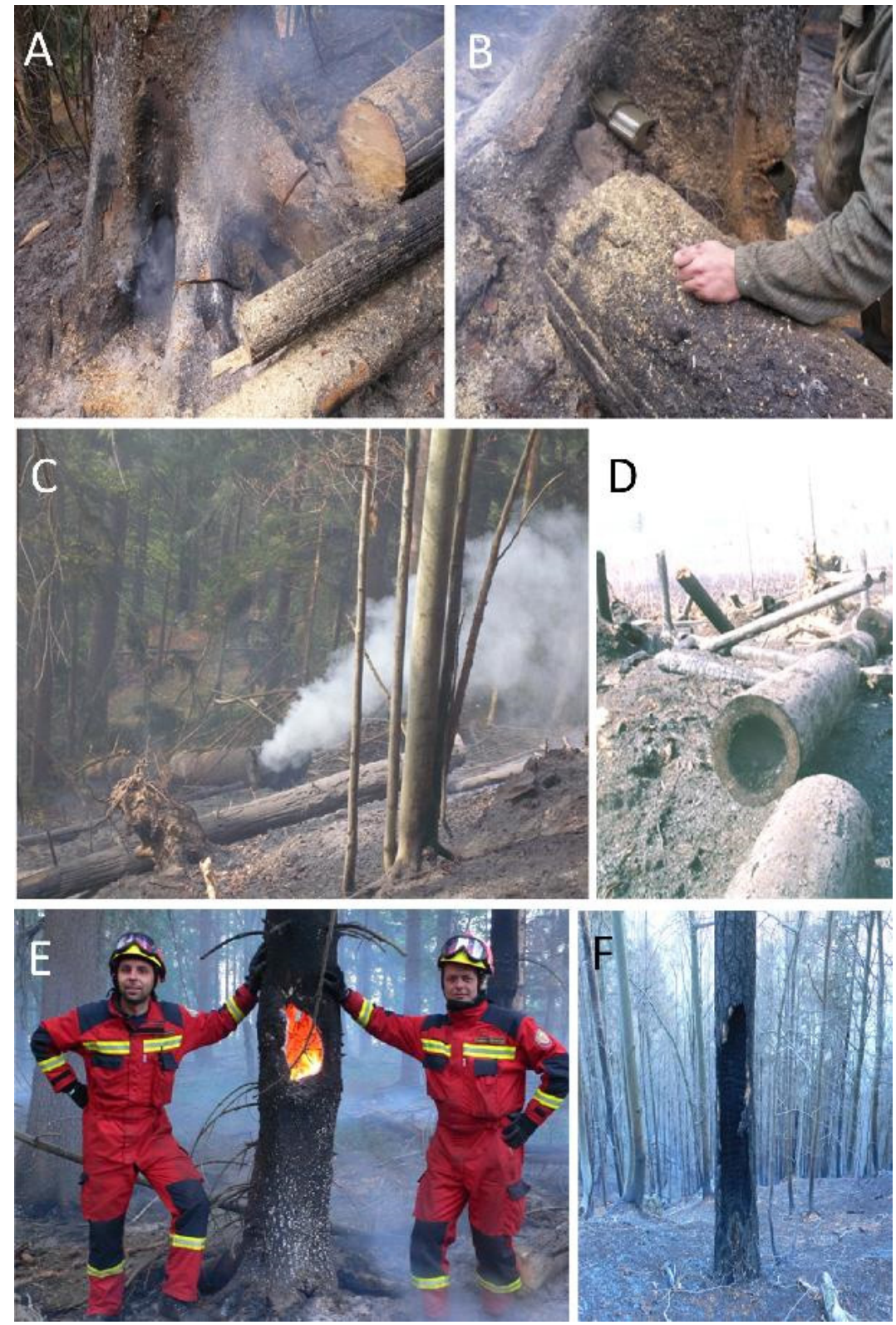

Fig. 4. Extinguishing burning trees with rot near the village of Staré Hory (Velká Fatra) on 15 April 2007 (48.8587644N, 19.1457272E) (Masica 2007) (photo I. Chromek). (A) Preparation cuts in the burning tree; (B) The use of explosive charges on a hollow tree with an inner fire at the top; (C) A tree with rot continues to burn even after it has been felled; (D) A hollow tree fire that has been extinguished; (E) A rotten tree that is still burning after the forest fire has moved through the area; and (F) A rotten tree in which the fire has been extinguished.

sprayed with water. This problem is especially important after the front of a forest fire has passed through an area (Fig. 4d) because, as noted earlier, the hidden fire in the rotten trees (Fig. 4e) can continue to burn even after it has been assumed to be extinguished. The hidden fire can then help reactivate the forest fire.

Therefore, both the standing and lying trunks must be checked. The above-mentioned method of fire for- est destruction is time-consuming but also demanding for personnel and water (up to $200 \mathrm{l}$ of water per $\mathrm{m}^{2}$ is required). An area with such trees must be repeatedly inspected. Rotten trees that have burned but are still standing are also dangerous because they are unstable and can fall on firefighters (Fig. 4f). Another risk involves rotten roots, which can burn and spread the fire ground (Pfeffer et al. 1961). 


\section{Discussion}

The number of hollow tree fires was very small in the Czech Republic (and is probably also very small in other countries of Central Europe), suggesting that this type of fire should not be considered as a separate category of forest fire. Rather than being recognized as a separate category, perhaps hollow tree fires should be considered as a part of other types of forest fires.

Hollow trees fires occur on trees with damage and rot. Tree injury results from mechanical damage to the trunk due to falling stones; peeling caused by sheep, goats, beef cattle, or game; or poor handling by foresters during cleaning, thinning, and logging 2 .

From 2006-2015, only three cases of hollow tree fires caused by lightning were documented in the FRS CR database, representing only $0.04 \%$ of all forest fires. Among all of the forest fires in the database, lightning caused a total of 96 fires, i.e., $1.32 \%$ of all fires.

Forests in the Czech Republic are intensively managed, and most forest fires are caused by human activity and not by lightning (Kula \& Jankovská 2013). The chances that fire is caused by lightning in the Northern Hemisphere increase with latitude. In areas just south of the Arctic Circle, lightning causes up to $90 \%$ of the natural fires (Post 1936). Because there are few people near the Arctic Circle, humans are unlikely cause fires in that region. In addition, that region has conditions that are extremely favorable for forest fires. The polar day in Alaska, for example, has 19 to $24 \mathrm{~h}$ of sunshine and temperatures as high as $37.3^{\circ} \mathrm{C}$, while the average annual precipitation is $<382 \mathrm{~mm}$ (Kunt 1967).

Earlier reports indicate that hollow tree fires in some countries have often been caused by shepherds who intentionally started fires in hollow trees (Pfeffer et al. 1961). We did not find any information in the scientific literature about whether shepherds intentionally started fires in hollow trees in Central Europe. Nechleba (1927) mentions that the careless manipulation of fire by human minors was often a cause of forest fires. In some cases, minors have intentionally started fires in tree cavities (e.g., see https://www.youtube. com/watch?v=XqnHRA-XNGw). This trend is evident today; from years 1974-1983, minors were responsible for approximately $7 \%$ of forest fires (Kula 1985a). In the years 1992-2004, the percentage decreased to $4.5 \%$ (Kula \& Jankovská 2013).

In the case of hollow tree fires, the tree burns to the height of the cavity or rot. If the cavity is at the bottom of the trunk, only this part burns. If the rot occurs higher, the fire can move up the stem and emerge from holes and cracks ((https://www.youtube.com/watch?v=LbxCFIbsKy0) (see Appendix A2)), from wounds (https://www.youtube.com/watch?v=p1dgewYCECU; http://www. wideopencountry.com/insane-footage-tree-fire-inside/; Fig. 4), and from holes formed by woodpeckers (http:// vtecostudies.org/blog/spring-wildfire/).

Extinguishing a single burning tree is not a complicated procedure (Krakovský 2004). Some older reports recommend clogging all holes in the hollow trunk with soil, or cutting down the tree and then extinguishing the fire (Hendrych 1956). There is currently no official way of dealing with hollow tree fires in the Czech Republic. In terms of felling, a burning hollow tree is generally felled in the same manner as a non-burning hollow tree (Appendix A3).

In some circumstances, the hollow tree can break apart or burst, such that hot coals fall to the litter and cause a surface fire (Hendrych 1956). If the surface fire spreads to young coniferous stands, a crown fire can develop, and a relatively small problem can become a large one (Pfeffer et al. 1961). In this case, the hollow tree fire becomes the source of a regular forest fire.

Although hollow tree fires are rare, hollow trees in forests commonly burn during forest fires. The occurrence of forest fires with burning rotten trees will increase as a consequence of the increasing area of forest stands with game damage. Game damage leads to rot. Trees damaged by game are more likely to be attacked by $S$. sanquinolentum (Čermák et al. 2004a, b; Čermák \& Strejček 2007).

\section{Conclusion}

Hollow tree fires are rare in the Czech Republic and lack many characteristics common to forest fires such as burnt area, head, flanks, and back of fire (Krakovský 2004). They also have relatively small economic and environmental consequences. We therefore conclude that hollow tree fires should not be considered a category of forest fire.

A stand-alone tree in a meadow would not be considered a forest, and if such a tree is ignited, it could not be called a forest fire. Similarly, if a hollow tree is ignited in a forest and burns without spreading, the event would not be considered a forest fire and would not generally be registered. If the fire spreads, it is by definition a forest fire and is no longer a hollow tree fire. We also note that hollow tree fires are not recognized as a category of forest fire in most of the countries in Central Europe, which only

\footnotetext{
${ }^{2}$ In the USA, fire can also produce tree damage in the form of basal cavities, which are ubiquitous in coast redwoods. They are common in the humid coastal forests of Del Norte County of California and also in the dry forests of the southernmost extent of the species range. Cavities result from a complex interaction between repeated fires and decay associated with two fungi, Poria sequoiae and Poria albipellucida. Coast redwood heartwood is remarkably decay- and fire-resistant, but these fungi thrive in sapwood behind newly formed fire scars (https://redwood.forestthreats.org/cavities.htm).
} 
recognize ground, surface, and crown fires as common types of forest fires (e.g., Forest Fires in Europe, Middle East and North Africa 2015) ${ }^{3}$.

On the other hand, the presence of rotten trees in forest stands is a serious threat. Such trees can become a long-lasting source of fire, and extinguishing them if they are burning is not straight forward. Because the numbers of trees with rot is increasing in the forests of the Czech Republic, firefighters should be trained in how to deal with such trees and should be advised of areas with stands where rotten trees are abundant.

\section{Acknowledgements}

This research was supported by the National Agency for Agricultural Research within the framework of projects no. QJ1620454 administered by the Ministry of Agriculture of the Czech Republic. The authors thank Dr. Bruce Jaffee (USA) for linguistic and editorial improvements.

\section{References}

Asiegbu, F. O., Abu, S., Stenlid, J., Johansson, M., 2004: Sequence polymorphism and molecular characterisation of laccase genes of the conifer pathogen Heterobasidion annosum. Mycological Research, 108:136-148.

Asiegbu, F. O, Adomas, A., Stenlid, J., 2005: Conifer root and butt rot caused by Heterobasidion annosum (Fr.) Bref. s.l. Molecular Plant Pathology, 6:395-409.

Asiegbu, F. O., Johansson, M., Woodward, S., Hütterman, A., 1998: Biochemistry of the host-parasite interaction. In: Woodward, S., Stenlid, J., Karjalainen, R., Hütterman A. (eds.): Heterobasidion annosum: Biology, Ecology, Impact and Control. CAB International. London, UK, p. 167-195.

Atta, H. A., Hayes, A. J., 1987: Decay in Norway spruce caused by Stereum sanguinolentum Alb. \& Schw. ex Fr. developing from extraction wounds. Forestry, 60:101-111.

Barchánek, V., 1932: Co je příčinou lesních požárů. Československý háj, 9:151.

Berger, F., Quetel, C., Dorren, L. K. A., 2002: Forest: a natural protection mean against rockfalls, but with which efficiency? In: Proceedings of the International Congress. Pacific Rim. Matsumoto, 2:815 -826.

Čermák, P., Glogar, J., Jankovský, L. 2004a: Damage by deer barking and browsing and subsequent rots in Norway spruce stands of Forest Range Mořkov, Forest District Frenštát p. R. (the Beskids Protected Landscape Area). Journal of Forest Science, 50:2430.
Čermák, P., Jankovský, L., Glogar J., 2004b: Progress of spreading Stereum sanguinolentum (Alb. et Schw.: Fr.) Fr. wound rot and its impact on the stability of spruce stands. Journal of Forest Science, 50:360-365. Čermák, P., Jankovský, L., Lička, D., Beránek, J., Glogar, J., 2004c: Damage to spruce stands by deer barking and subsequent rots in Forest Range Proklest, the Krrtiny Training Forest enterprise "Masaryk Forest" (the Drahany upland). Acta Universitatis Agriculturae et Silviculturae Mendelianae Brunensis, Sborník Mendelovy zemědělské a lesnické univerzity v Brně, 2:165-174.

Čermák, P., Strejček, M., 2007: Stem decay by Stereum sanguinolentum after red deer damage in the Českomoravská vrchovina Highlands. Journal of Forest Science, 53:567-572.

Černý, A., 1989: Parazitické dřevokazné houby. Praha, SZN, 104 p.

Černý, A., 2001: Pevník krvavějící Haematosterum sanguinolentum Pouz. comb. novum., významná parazitická dřevokazná houba rozšířená v jehličnatých lesích v mírných pásech na celém světě. Reports of Forestry Research, 46:122.

Chromek, I., 2006: Využitie leteckej techniky pri hasení lesných požiarov. Zvolen, Technical University in Zvolen.

Donaubauer, E., 1994: Zur Wildschadenssituation in Europa. Salzburg, Proceedings CIC tagung, $11 \mathrm{p}$.

Dorren, L.K.A., Berger, F., 2005: Stem breakage of trees and energy dissipation during rainfall impacts. Tree Physiology, 26:63-71.

Eriksson, K.E., Pettersson, B., 1968: Extracellular enzyme system utilized by the rot fungus Stereum sanguinolentum for the breakdown of cellulose: II. Archives of Biochemistry and Biophysics, 124:142148.

Felix, Z., 1948: Požární ochrana lesů. Hasičská knihovnička Jiskra, 6:100.

Forest Fire in Europe, Middle East and North Africa, 2015 [online] [2017-03-27]: European Communities, Luxembourg, 2016.

Forst, P., (ed.), 1970: Ochrana lesů. Praha, SZN, 423 p.

Franc, R., 2004: Prevence a hašení lesních požárů vČR, organizace jednotek požární ochrany. In:Lesní požáry. Czech University of Life Sciences Prague, p. 35-40.

Francl, R., 2007: Lesní požáry v České republice z pohledu hasičů. Lesnická práce, 8:16-19.

Guyette, R.P., Stambaugh, M.C., 2004: Post-oak fire scars as a function of diameter, growth, and tree age. Forest Ecology and Management, 198:183-192.

\footnotetext{
${ }^{3}$ In Poland, however, fires are divided into four types: 1) individual tree fires, 2) ground fires (peat, peat-muck), 3) surface fires, and 4) forest stand fires. A fire involving only one tree is extremely rare in Poland and is the result of arson or lightning strikes. In the case of arson, the fire can transform into any other kind of fire. In the case of lightning strikes, the threat of fire spread is small because lightning is usually accompanied by rain in Poland Predecka 2011).
} 
Han, H. S., Kellogg, L. D., 2000: Damage characteristics in young Douglas-fir stands from commercial thinning with four timber harvesting systems. Western Journal of Applied Forestry, 15:27-33.

Hendrych, V., 1956: Ochrana lesů. Praha, SZN, 260 p.

Hlaváč, P., 2003: Človek najviac prispieva k vzniku lesných požiarov. Enviromagazín, 2:26-27.

Hlavač, P., 2005a: Základné typy lesných požiaroch a jejich způsoby hašenia lesným personálom. In: Kodrík, M., Hlaváč, P. (eds.): Uplatňování nových metod v ochraně lesa a ochraně krajiny. Technical University in Zvolen, p. 209-214.

Hlavač, P., 2005b: Základné lesnícké charakteristiky protipožiarnych prvkov navrhnutých pre ochranu kalamitneho územia TANAP pred požiarmi. In: Kodrik, M., Hlaváč, P. (eds.): Uplatňování nových metod v ochraně lesa a ochraně krajiny. Technical University in Zvolen, p. 223-227.

Hlaváč, P., Chromek, I., 2016: Lesné požiare a integrovaný systém ochrany lesov před požiarmi. Zvolen, Technical University in Zvolen, 81 p.

Hlaváč, P., Chromek, I., Majlingová, A., Osvald, A., 2005: Projekt protipožiarnej ochrany lesa na území Vysokých Tatier po vetrovej kalamite: realizačný projekt. Zvolen, Technical University in Zvolen, 67 p.

Hlaváč, P., Chromek, I., Majlingová, A., 2009: Od Projektu protipožiarnej ochrany lesa vo Vysokých Tatrách po vetrovej kalamite po zmeny legislatívy v oblasti ochrany lesov pred požiarmi v podmienkach Slovenskej republiky. Zvolen, Technical University in Zvolen, 145 p.

Hodr, J., 1963: Požarní ochrana v zemědělství a lesním hospodářství. Praha, SZN, 378 p.

Homolka, M., 1995: Některé aspekty potravní ekologie vybraných druhů zvěře ve vztahu k problematice obnovy lesních ekosystémů. In: Škody zvěří a jejich řešení. The Faculty of Forestry and Wood Technology at Mendel University in Brno, p. 35-39.

Hrádek, M., Kolejka, J., Švehlík, R., 1997: Czechia and Slovakia. In: Embleton, C., Embleton-Hamann, C. (eds.): Geomorphological Hazards of Europe. Elsevier Science. Amsterdam, Neetherlands, p. 64-66.

Huse, K. J., Venn, K. 1994: Vertical spread of Heterobasidion annosum in stems of Norway spruce. In: Johansson, M., Stenlid, J. (eds.): Proceedings of the 8th IUFRO Conference on Root and Butt Rots. Swedish University of Agricultural Sciences. Uppsala, Sweden, p. 208-212.

Hüttermann, A., 1980: Biochemical studies on Fomes annosus. In: Dimitri, L. (eds.): Proceedings of the Fifth IUFRO Conference on Problems of Root and Butt Rot in Conifers. Hessische Forstliche Versuchsanstalt. Hann. Munden, Germany, p. 109-123.

Isomäki, A., Kallio, T., 1974: Consequences of injury caused by timber harvesting machines on the growth and decay of spruce (Picea abies [L.] Karst.). Acta Forestalia Fennica, 136:25.

Johansson, M., 1988: Pectic enzyme activity of spruce (S) and pine (P) strains of Heterobasidion anno- sum. Physiological and Molecular Plant Pathology, 33:333-349.

Karlsson, J.O., Stenlid, J., 1991: Pectic isozyme profiles of the intersterility groups in Heterobasidion annosum. Mycological Research, 95:531-536.

Kiser, J., 2011: Histochemical and geometric alterations of sapwood in costal Douglas-fir following mechanical damage during commercial thinning. Silva Fennica, 45:729-741.

Klich, D., 2015: Similarities in foraging patterns of wisent, red deer and various breeds of European primitive horses. The European Bison Conservation Center Newsletter, 8:41-51.

Klich, D., 2017: Selective bark stripping of various tree species by Polish horses in relation to bark detachability. Forest Ecology and Management, 384:65-71.

Korhonen, K., Stenlid, J., 1998: Biology of Heterobasidion annosum. In: Woodward, S., Stenlid, J., Karjalainen, R., Hütterman, A. (eds.): Heterobasidion annosum: Biology, Ecology, Impact and Control. CAB International. London, UK, p. 43-71.

Krakovský, A., 2004: Lesné požiare. Zvolen, Technical University in Zvolen, 78 p.

Kř́ístek, J. (ed.), 2002: Ochrana lesů a přírodního prostředí. Písek, Matice lesnická, 386 p.

Křístek, Š., 2008: Lesní pastva v ukrajinských Karpatech. Lesnická práce, 87:36-37.

Kučera, 1914: Lesní požáry. Háj, 33:237-238.

Kučera, M., Adolt, R., Kohn, I., Piškytlová, K., Kratěna, L., Fejfar, J. et al., 2016: Výstupy Národní inventarizace lesů uskutečněné v letech 2011-2015, 11. Škody zvěří na lesních porostech. Lesnická práce, 95.

Kuiters, A. T., Van Der Sluijs, L. A. M., Wytema, G. A., 2006: Selective bark-stripping of beech, Fagus sylvatica, by free-ranging horses. Forest Ecology and Management, 222:1-8.

Kula, E., 1981: Lesní požáry v ČSSR. Lesnictví, 27:545566.

Kula, E., 1985a Výskyt a příčiny lesních požárů v ČSSR (1979-1983). Acta Universitatis Agriculturae et Silviculturae Mendelianae Brunensis, series C, 54:225-246.

Kula, E., 1985b: Výskyt a prŕíčiny lesních požárů v ČSSR (1979-1983). Acta Universitatis Agriculturae et Silviculturae Mendelianae Brunensis, series C, 54:225246.

Kula, E., Jankovská, Z., 2013: Forest fires and their causes in the Czech Republic (1992-2004). Journal of Forest Science, 59:41-53.

Kunt, A., 1967: Lesní požáry. Prague, Českosloslovenský svaz požární ochrany, 313 p.

Lutz, H. J., 1980: Effect of cattle grazing on vegetation of a virgin forest in Northwestern Pennsylvania. Journal of Agricultural Research, 41:561-570.

M., M., 1948: Boj proti lesním požárům. Lesnická práce, 27:264-266.

Machander, V., 2016: Požáry lesních porostů a jejich prevence. Zpravodaj LOS, 16:51-55. 
Maijala, P., Raudaskoski, M., Viikari, L., 1995: Hemicellulolytic enzymes in P- and S-strains of Heterobasidion annosum. Microbiology, 141:743-750.

Maijala, P., Harrington, T.C., Raudaskoski, M., 2003: A peroxidase gene family and gene trees in Heterobasidion and related genera. Mycologia, 95:209-221.

Mäkinen, H., Hallaksela, A.M., Isomäki, A., 2007: Increment and decay in Norway spruce and Scots pine after artificial logging damage. Canadian Journal of Forest Research, 37:2130-2141.

Malík, V., Karnet, P., 2007: Game damage to forest trees. Journal of Forest Science, 53:406-412.

Mansson, J., Jarnemo, A., 2013: Bark-stripping on Norway spruce by red deer in Sweden: level of damage and relation to tree characteristics. Scandinavian Journal of Forest Research, 28:117-125.

Masica, V., 2007 [online] [2017-08-16]: Lesný požiar Staré Hory. ForestPortál o lesoch Slovenska.

Mayer, H., Ott, E. K., 1991: Gebirgswaldbau - Schutzwaldpflege. Ein waldbaulicher Beitrag zur Landschaftsökologie und zum Umweltschutz, 2., vollständig neu bearb. Stuttgart, Fischer, 587 p.

McIntyre, E. B., 1972: Barkstripping - a natural phenomenon. Scottish Forestry, 26:43-50.

Meadows, J. S., 1993: Logging damage to residual trees following partial cutting in a green ash-sugarberry stand in the Mississippi Delta. In: Proceedings of 9th Central Hardwood Forest Conference, USDA Forest Service, Southern Forest Experiment Station, U.S., p. 248-260.

Mitchell, B., Staines, B. W., Welch, D., 1977: Ecology of red deer-A research review relevant to their management in Scotland. Cambridge, Institute of Terrestrial Ecology, 74 p.

Nechleba, A., 1927: Lesní požáry. Sborník CAZ II, 4:569-651.

Nestěrov, V.G., 1949: Ochrana proti požiarom. Bratislava, $233 \mathrm{p}$.

Nord, F. F., Hata, K., 1969: Fungal degradation of pine bark lignin. In: Kaplan, N. O., Kennedy, E. P. (eds.): Current Aspects of Biochemical. Academic Press, New York, U.S., p. 315-329.

Ohman, J.H., 1970: Value loss from skidding wounds in sugar maple and yellow birch. Journal of Forestry, 68:226-230.

Okada, T., Takeda, K., Hokura, K., Takahashi, S., 2007: Peeling damage to trees caused by cows grazing in an old larch forest. Bulletin of the Shinshu University Alpine Field Center, 5:51-54.

Pfeffer, A., 1938: Lesní požáry v Československé republice v r. 1934. Prague, Státní výzkumný ústav pro ochranu lesů v Praze, 43 p.

Pfeffer, A., (ed.), 1961: Ochrana lesů. Praha, SZN, 838 p.

Pohořelý, M., Vilhelm, V., 1996: Lesní požáry a prevence. Praha, Česká pojištovna, 83 p.

Post, E., 1936: Systematische und pflanzengeographische Notizen zur Bostrychia-Caloglossa-assoziation. Revue algologique, 9:1-84.
Predecka, A., 2011: Ogień w lesie a przyrode. Warsaw, Dyrekcja Generalna Lasów Państwowych, 166 p.

Půlpán, L., 2001: Vliv hospodaření na vznik hnilob. Zprávy lesnického výzkumu, 46:135-136.

Reimoser, F., 2003: Steering the impact of ungulates on temperate forests. Journal for Nature Conservation, 10:243-252.

Rönnberg, J., Berglund, M., Johansson, U., Cleary, M. 2013: Incidence of Heterobasidion spp. following different thinning regimes in Norway spruce in southern Sweden. Forest Ecology and Management, 289:409-415.

Shigo, A. L., 1986: A new tree biology. Durham, New Hampshire, Shigo \& Tree Associates, 595 p.

Sloup, M., Raba, J., 2004: Lesní hospodářství a požáry. In: Lesní požáry. Czech University of Life Science, p. $14-16$.

Stolina, M. (ed.),1985: Ochrana lesa. Bratislava, Príroda, 473 p.

Stolina, M., Kodrík, J., Novotný, J., Konôpka, J., Hlaváč, P., 2001: Ochrana lesa. Technical University in Zvolen, p. 67-75.

Sviták, M., 2004: Požár rašeliny a lesního porostu Hrdlorezy u Nových Hradu. In: Lesní požáry. Czech University of Life Science.

Svoboda, S., 1952: Život lesa. Prague, Brázda, 147 p.

Tomášek, L., 2004: Organizace prevence protivzniku lesních požáru u podniku Lesy České republiky. In: Lesní požáry. Czech University of Life Science, p. 17-23.

Tomášek, L., 2007 [online] [2017-07-10]: Prevence vzniku lesních požárů u LČR. Lesnická práce, 86.

Turček, F. J., Lehotan, T., 1949: Lesné požáre na Slovensku v r. 1947. Ročenka státního výzkumného ústavu 1:132-141.

Vasiliauskas, R., 2001: Damage to trees due to forestry operations and its pathological significance in temperate forests: a literature review. Forestry, 74:319-336.

Vasiliauskas, A., Stenlid, J., 2007: Discoloration following bark stripping wounds on Fraxinus excelsior. European Journal Forest Pathology, 28:383-390.

Vlad, R., 2014: Assessment of the wood volume with stem decay in Norway spruce stands damaged by red deer. In: Proceedings of the Biennial International Symposium. Forest and sustainable development. Transilvania University Press, Brașov, Romania, p. 381-386.

Vlad, R., Sidor, C. G., 2013: Research for the estimate of rotten stem wood volume in Norway spruce stand damaged by deer species. Revista Pădurilor, 128:2732.

Welsch, D., Scott, D., Staines, B., 1997: Bark stripping damage by red deer in Sitka spruce in Western Scotland. III. Trends in wound condition. Forestry, 70:113-120.

Zeidler, A., 2012 [online] [2017-07-10]: Lexikon vad dřeva. Prague, Czech University of Life Sciences.

Zpráva o stavu lesa a lesního hospodářství České republiky v roce 2015, 2016. Praha, Ministerstvo zemědělství, 133 p. 


\section{Appendix A1. Internet links to hollow tree fires that are not included in FRS CR database:}

26. září 2012 - Požár stromu. [online] [2017-07-10]:Avalaible at: http://hasiciht.wz.cz/hasiciht.wz.cz/2012/09/26zari-2012-Pozar-stromu.html

3. Požár dutého stromu. [online] [2017-07-10]: Avalaible at: http://hasici.stenovice.cz/index.php?option=com_ content\&view=article\&id=147:3-poar-duteho-stromu\&catid=39:2008\&Itemid=101

Hořel dutý kmen stromu i celý les, 2015: [online] [2017-07-10]. Avalaible at: https://www.regionvalassko.cz/aktuality_zobraz.php?lang=1\&id=198\&akt=9488\&page=33

Kohout, J., 2015: Sucho zaměstnává hlavně hasiče. Oheň řádil u Trpíst. [online] [2017-07-10]. Avalaible at: http:// tachovsky.denik.cz/pozary/sucho-zamestnava-hlavne-hasice-ohen-radil-u-trpist-20150805.html

Kolischová, L., 2011: Nedopalek zapálil 150 let starý platan, strom už asi nepůjde zachránit. [online] [2017-0710]. Avalaible at: http://zpravy.idnes.cz/horel-vzacny-150-let-stary-strom-mozna-uz-nepujde-zachranit-pnh-/ domaci.aspx?c=A110403_130318_olomouc-zpravy_kol

Marvan, L., 2012: Ve Velkém Šenově hořel třicetimetrový strom, někdo ho zapálil. [online] [2017-07-10]. Avalaible at: https://www.pozary.cz/clanek/54931-ve-velkem-senove-horel-tricetimetrovy-strom-nekdo-ho-zapalil/

Marvan, L., 2015: Hromy a blesky létaly také nad Litoměřickem. [online] [2017-07-10]. Avalaible at: http://litomericky.denik.cz/zpravy_region/hromy-a-blesky-letaly-take-nad-litomerickem-20150428.html

Požár dutého stromu 2.8.2015, 2015: [online] [2017-07-10].Avalaible at:http://www.hasicihrusky.cz/news/pozarduteho-stromu/

Sbor dobrovolných hasičů Kovářská, 2012: 14.9.2012 Lesní revír Špičák - požár stromu. [online] [2017-07-10]. Avalaible at: http://www.hasicikovarska.ic.cz/2012/2012-09-14/index.htm 
Appendix A2. Case study: Fighting a fire that was intentionally started by humans in lime trees
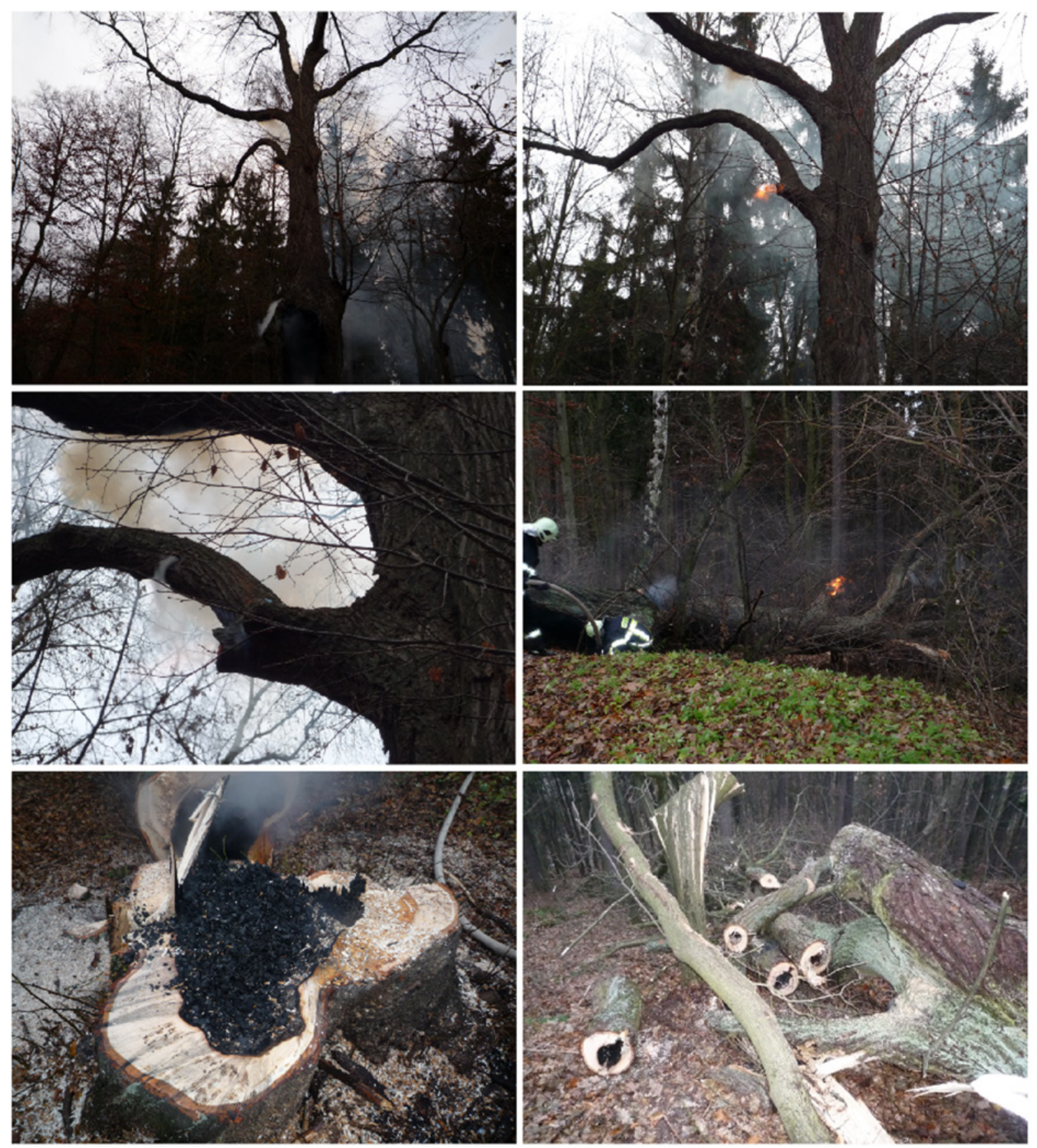

Fig. A.1. Fighting an intentionally set fire in lime trees on the border of a mixed forest on 3 December 2011 (photo J. Vaněk).

Comment:

On 3 December 2011, a fire that was intentionally started in a hollow lime tree was found on the border of a mixed forest. The burning hollow lime tree was located in the alley leading to the chapel at the top of Zámecký vrch in Stráž pod Ralskem. A stream of water was first used to extinguish the fire in the tree trunk, but this did not eliminate the entire fire. Either because of a branch break or a tree cut, a chimney effect occurred, and the fire moved up the trunk and into the branches. The tree was then felled and sprayed with water. The tree was finally cut into smaller pieces and was again sprayed with water (Fig. A.1). 


\section{Appendix A3. Firefighting procedures for hollow trees}

In practice, there are two methods to eliminate this type of fire:

\section{1) Fighting the fire in the upright tree}

This is clearly the safer and easier of the two methods. It is more likely to be used with coniferous trees. Because such trees have relatively thin branches that are oriented downward at a sharp angle, the fire tends to remain in the trunk. The burning often results in holes in trunk where rotten branches were present. Firefighters will spray water into these holes as a way to get water into the burning, interior trunk. It is also possible to spray water into holes that the firefighters have drilled into the trunk.

\section{2) Fighting the fire by first felling the tree}

This method is used with deciduous trees because both the trunk and skeletal branches of such tree are often affected by fire. Tree branches located high in the canopy do not usually burn. Skeletal branches that are oriented upward will help spread the fire. Fires in deciduous trees with many branches can be difficult to extinguish because the branches prevent the sprayed water from contacting smouldering branches. As a result, the risk of fire reactivation is high, and the fire can reactivate even after appearing to be extinguished for several days.

In this method, firefighters must be aware of the risk of falling branches. They must also be aware that during the felling process, the gas exchange conditions can change significantly and may increase the intensity of the fire. The firefighters can be damaged by both flames and radiant heat. Firefighters must also consider that in felling rotten and hollow trees, controlling the direction of the tree's fall may be difficult. Firefighters must further consider that the entire weight of the tree is supported only by the outer circular layer of wood and that such trees may therefore collapse without warning. Wedging of these trunks is usually not recommended because there is not enough wood around the circumference of the trunk to make wedging effective. Rather than cutting the tree, it might be possible to drop the tree with a rope.

Once the tree is felled, the flow of air and combustion gases inside the trunk will decrease, reducing the intensity of the fire. To facilitate the penetration of the extinguishing substance into the trunk, the felled tree can be cut into smaller parts. When cutting, a prepared water stream should be available to prevent the spread of fire to the surrounding trees. 